\title{
Sediment Contaminant Bioaccumulation: With or Without Gut Contents?
}

\author{
Peter M. Chapman ${ }^{1}$
}

Received: 17 March 2016/ Accepted: 21 March 2016/Published online: 28 March 2016

(C) Springer Science+Business Media New York 2016

Over 30 years ago I published a 3-page note in this journal (Chapman 1985) warning that "sediment gut contents significantly influence determinations of tissue metal levels in invertebrates", and suggesting either effective depuration prior to chemical analyses or a gut sediment correction. I noted that metal loads contributed by the gut sediments varied from $15 \%$ to $60 \%$ of the total metal loads in the oligochaete worms and lamprey larvae I collected and analyzed. That note was cited in a number of subsequent publications that assessed the effects of gut contents on not only whole body chemical analyses (Hare et al. 1989; Lobel et al. 1991; Robinson et al. 1993; Brooke et al. 1996; Mount et al. 1999; Neumann et al. 1999; Goodyear and McNeill 1999; Bat and Raffaelli 1999) but also on dry weight estimates of growth (Sibley et al. 1997). Overestimates of whole body contaminant concentrations due to gut sediment contents ranged as high as $438 \%$ (Neumann et al. 1999).

The contribution of gut sediment to whole body chemical analyses increases as biota sediment accumulation factors decrease and can be contaminant- and sedimentspecific (Neumann et al. 1999). For example, ingestion of sediments that contain high proportions of black carbon particles will result in overestimates; those particles tend to bind organic contaminants such as PAHs and PCBs, such that they are not readily biologically available (Koelmans et al. 2006).

Failing to depurate or correct for gut contents increases the probability of either false positives or false negatives in

Peter M. Chapman

peter@chapmanenviro.com

1 Chapema Environmental Strategies Ltd., 1324 West 22nd St, North Vancouver, BC V7P 2G4, Canada sediment toxicity tests measuring growth in terms of weight; false negatives will occur for sediments with high proportions of silt and sand that are likely to be ingested in large quantities (Sibley et al. 1997). All organisms used in sediment toxicity tests will ingest sediment, including water column organisms such as Daphnia (Gillis et al. 2004).

Gut sediment corrections can be applied in different ways depending on the study intent. To determine contaminant concentrations in living tissues either dissect out the gut sediments (time consuming) or measure contaminant concentrations in the sediment the organisms feed in, collect and weigh the sediments in their guts after chemical analyses of the whole organism, and then calculate the contaminant concentrations in the gut sediments relative to the analytical results (Eq. 1):

$[\mathrm{CC}]_{\mathrm{b}}=\mathrm{W}[\mathrm{CC}]_{\mathrm{t}}-\mathrm{W}_{\mathrm{g}}[\mathrm{CC}]_{\mathrm{s}} / \mathrm{W}_{\mathrm{t}}-\mathrm{W}_{\mathrm{g}}$

where $\quad[\mathrm{CC}]=$ contaminant $\quad$ concentration $\quad(\mathrm{mg} / \mathrm{kg})$, $\mathrm{W}=$ weight $(\mathrm{g}), \mathrm{b}=$ entire body without gut contents, $\mathrm{t}=$ entire body including gut contents, $\mathrm{g}=$ gut, and $\mathrm{s}=$ sediment on which the organism fed.

This latter method is reasonably equivalent to dissection when the gut contents are mainly sediment (Hare et al. 1989), but not when the guts contain other materials (Cain et al. 1995). To determine growth in terms of dry weight: oven-dry and weigh the organisms, then ash them and weigh the residue; the ash-free dry weight is the difference between the two measurements.

Whether guts are depurated or a gut sediment correction is applied will depend on the specific contaminants of concern, the specific biota, and the specific study aims. Depuration of gut sediment contents also allows for depuration of tissue-bound chemicals. This is of particular concern for contaminants with a $\log \mathrm{K}_{\mathrm{ow}}<5$, which 
require adjusting depuration times relative to body depuration rate constants to "balance the diminishing bias from gut contents against the growing bias from depuration" (Mount et al. 1999). A gut sediment correction rather than depuration will be required when coprophagy occurs unless measures are taken to avoid feces ingestion such as feeding with an uncontaminated artificial food of constant quality (Neumann et al. 1999).

Depuration or gut sediment corrections may not, however, be appropriate when the goal is to assess contaminant concentrations in prey, given that ingestion of the organism plus its stomach contents will occur, and digestive juices may release sediment contaminants (Weston and Maruya 2002; Rust et al. 2004). Gut contents should be included in laboratory-field comparisons where field specimens include uncorrected gut contents; also, depuration is not appropriate for low-molecular-weight contaminants such as PAHs, which can be depurated rapidly (Van Geest et al. 2010).

As noted above, there are cases when gut sediment contents should be excluded from analyses and others where they should not be. Further, neither depuration nor gut sediment corrections are without uncertainties. These uncertainties in addition to uncertainties in chemical analyses mean that definitive single numerical values are unrealistic. Inappropriately ignoring contributions from gut sediment contents will result in even greater deviations from reality.

\section{References}

Bat L, Raffaelli D (1999) Effects of gut sediment contents on heavy metal levels in the amphipod Corophium volutator (Pallas). Turk J Zool 23:67-71

Brooke LT, Ankley GT, Call DJ, Cook PM (1996) Gut content and clearance for three species of freshwater invertebrates. Environ Toxicol Chem 15:223-228

Cain DJ, Luoma SN, Axtmann EV (1995) Influence of gut content in immature aquatic insects on assessments of environmental metal contamination. Can J Fish Aquat Sci 52:2736-2746
Chapman PM (1985) Effects of gut sediment contents on measurements of metal levels in benthic invertebrates - a cautionary note. Bull Environ Contam Toxicol 35:345-347

Gillis PL, Chow-Fraser P, Ranville JF, Ross PE, Wood CM (2004) Daphnia need to be gut-cleared too: the effect of exposure to and ingestion of metal-contaminated sediment on the gut-clearance patterns of D. magna. Aquat Toxicol 71:143-154

Goodyear KL, McNeill S (1999) Bioaccumulation of heavy metals by aquatic macro-invertebrates of different feeding guilds: a review. Sci Tot Environ 229:1-19

Hare L, Campbell PGC, Tessier A, Belzile N (1989) Gut sediments in a burrowing mayfly (Ephemeroptera, Hexagenia limbata): their contribution to animal trace element burdens, their removal, and the efficacy of a correction factor for their presence. Can J Fish Aquat Sci 46:451-456

Koelmans AA, Jonker MTO, Cornelissen G, Bucheli TD, Van Noort PCM, Gustafsson Ö (2006) Black carbon: the reverse of its dark side. Chemosphere 63:365-377

Lobel PB, Belkhode SP, Jackson SE, Longerich HP (1991) Sediment in the intestinal tract: a potentially serious source of error in aquatic biological monitoring programs. Mar Environ Res 31:163-174

Mount DR, Dawson TD, Burkhard LP (1999) Implications of gut purging for tissue residues determined in bioaccumulation testing of sediment with Lumbriculus variegatus. Environ Toxicol Chem 18:1244-1249

Neumann PTM, Borgmann U, Norwood W (1999) Effect of gut clearance on metal body concentrations in Hyalella azteca. Environ Toxicol Chem 18:976-984

Robinson WE, Ryan DK, Wallace GT (1993) Gut contents: a significant contaminant of Mytilus edulis whole body metal concentrations. Arch Environ Contam Toxicol 25:415-421

Rust AJ, Burgess RM, McElroy AE, Cantwell MG, Brownawell BJ (2004) Influence of soot carbon on the bioaccumulation of sediment-bound polycyclic aromatic hydrocarbons by marine benthic invertebrates: an interspecies comparison. Environ Toxicol Chem 23:2594-2603

Sibley PK, Monson PD, Ankley GT (1997) The effect of gut contents on dry weight estimates of Chironomus tentans larvae: implications for interpreting toxicity in freshwater sediment toxicity tests. Environ Toxicol Chem 16:1721-1726

Van Geest JL, Poirier DG, Sibley PK, Solomon KR (2010) Measuring bioaccumulation of contaminants from field-collected sediment in freshwater organisms: a critical review of laboratory methods. Environ Toxicol Chem 29:2391-2401

Weston DP, Maruya KA (2002) Predicting bioavailability and bioaccumulation with in vitro digestive fluid extraction. Environ Toxicol Chem 21:962-971 